\title{
Development of Mind Mapping Learning Model Based on Gusjigang Local Wisdom Based on Grade IV Elementary School students in Kudus
}

\author{
Ivan Ahmad Shofyan \\ \{Ivanahmad79@yahoo.com\} \\ Master of Basic Education Study Program, Faculty of Teacher Training and Education, Universitas \\ Muria Kudus, Indonesia
}

\begin{abstract}
This study purpose to develop a Mind Mapping learning model based on Gusjigang Local Wisdom in fourth grade students of Primary Schools in Kudus. This type of research uses research and development methods (R\&D) which have been simplified into 8 steps. Data collection in this study was done by observation, interviews, questionnaires, documentation, and tests. This research was conducted in class IV SD 1 Gribig, SDIT Lukmanakim, and SD 1 Gamong. This development produces components, namely: 1) the syntax of the model; 2) social system; 3) The principle of reaction; 4) Support system; 5) Instructional impact and accompaniment impact. The results of the effectiveness test using PTK, showed that there was an increase in learning outcomes in aspects of attitude, knowledge, and skills. 1) Aspects of attitude, SD 1 Gribig and SDIT Lukman Hakim increased $91 \%$ in cycle II. SD 1 Gamong increased in cycle II $89 \%$. 2) Knowledge aspects, SD 1 Gribig and SDIT Lukman Hakim, and SD 1 Gamong increased to $100 \%$ in cycle II. 3) Aspects of skills, SDIT Lukman Hakim increased in cycle II 86. SD 1 Gribig cycle increased in cycle II 85. SD 1 Gamong increased in cycle II 83.
\end{abstract}

Keywords: Development, Mind Mapping Learning Model, Gusjigang 


\section{INTRODUCTION}

Learning activities is a condition that is intentionally created by the teacher to provide knowledge and experience to students. There are several problems in education so far that might be considered very trivial namely a very ordinary learning model and less attractive to students. Based on the results of unstructured observations and interviews in the three schools that will be studied obtained information that; 1) the teacher has not used the learning model to the fullest, 2) the teacher in teaching does not attract the attention of students, so students are partially unfocused, 3) the lack of introduction of Kudus local wisdom towards students, 4) student motivation to learn less passionate, and 5) lack of availability learning model books as reference material for teachers in teaching.

For this reason, researchers intend to use the Mind Mapping learning model based on Gusjigang's local wisdom in Kudus district to improve teacher quality and learning outcomes. Mind Mapping itself is a learning strategy developed as an effective method for developing ideas through a series of concept maps. Whereas Gusjigang's local wisdom is the teachings of Sunan Kudus which have good meaning, clever Koran, and clever trade. It is expected that in addition to the teacher teaching with the Mind Mapping model, it can also introduce Gusjigang's local wisdom towards children, because the value of Gusjigang is very important to foster children's character.

\section{LITERATURE REVIEW}

\subsection{Mind Mapping Learning Model}

Mind Mapping is a technique to summarize the material that needs to be studied, and project the problem at hand in the form of maps or graphical techniques so that it is easier to understand. This learning model is the most effective way to enter, store and extract data from or to the brain. In mind mapping, the two sides of the brain function according to their respective portions. With a combination of colors, images and curved branches, it will be visually stimulating, so that the information obtained is easy to remember. Mind mapping is one way to record subject matter that makes it easy for students to learn. In addition this model is also categorized as a creative learning technique because in making this mind mapping it takes imagination from the making.

Mind mapping can be used to visualize, design, record, solve problems, make decisions, revise, and clarify the main topic, so that students are able to do even a lot of tasks. So the mind mapping learning model is suitable for use in almost all fields of study. This learning model was first introduced by Buzan in the early 1970s. Tony Buzan believes that the use of mind mapping is not only able to jump-start the memory process, but also can improve creativity and analytical skills, and optimize the function of the cerebral hemispheres. Suprijono (2012: 106) another way to strengthen students' knowledge and understanding of the materials they have read is the concept map learning method. The things that need to be prepared are pieces of cards that read the main concepts.

Whereas Huda (2013: 307) explained the Mind Mapping learning strategy was developed as an effective method for developing ideas through a series of maps. One of the initiators of this method is Buzan (2004). To make Mind Mapping, according to Buzan, a person usually starts by writing the main idea in the middle of the page and from there he can spread it in all directions to create a kind of diagram consisting of key words, phrases, concepts, facts, facts, and pictures.

Before making a mind mapping, we need to prepare the ingredients, which are blank paper, colored pencils, imagination pens, and our own brains. Buzan stated, there are seven steps in making mind mapping. The seven steps are as follows: 
1. Starting from the middle of a blank sheet of paper that is placed horizontally.

2. Using a central image or photo.

3. Using attractive colors.

4. Connect the main branches to the center image, and connect the second and third-level branches to the first and second levels, and so on.

5. Creating a curved line, not a straight line will bore the brain.

6. Use one keyword for each line.

7. Using images.

\subsection{Kudus Local Wisdom Gusjigang}

Gusjigang's philosophy is the teaching of Sunan Kudus. He is the founding elder of the city of Kudus and one of the Wali Songo named Syeh Ja'far Shodiq. The implementation of the Gusjigang was applied in the steps of the Mind Mapping learning model. The meaning of "Gusjigang" that is inserted in these learning steps is the word gus "good" can represent (attitude), ji word "Koran" to explore knowledge by learning and the word "trade" represents the entrepreneurial spirit of students.

Gusjigang itself has a meaning of good morals, clever Koran and clever merchants. Gusjigang's teachings affected local residents as religious and smart trading communities. The existence of mosques and Islamic boarding schools close to the market reinforces the principles of Gusjigang. Ismaya (2013), found that for the 30-60 year old generation, Gusjigang's philosophy can be understood and implemented in daily life, especially for those who live around the Menara mosque.

For children and adolescents now, Gusjigang's philosophy is something strange and strange. Foreigners are proven by their ignorance of Gusjigang. Strange because for children and adolescents, Gusjigang is outdated and outdated. So it is not strange and not strange that now many children and adolescents do not know, let alone understand and carry out Gusjigang's philosophy. Over time, many teenagers who do not know the meaning of gusjigang are undeniable evidence of how low the interest of young people today to just know what Gusjigang's philosophy is, let alone understand and apply it as a basis for daily life. For this reason, an educational effort regarding Gusjigang's philosophy is needed for children and adolescents, so that the existence of Gusjigang's philosophy is maintained and sustainable in the Kudus community as a form of social capital, local culture, local wisdom and moral teachings

The following explanation is about Gusjigang:

1. Gus or bagus, as soft skill is an abbreviation of good, which means good character and character. The kudus Community, especially followers or students of Sunan Kudus, are taught how to become human beings who have noble character to save the afterlife. Someone who is close to God is someone who must have good morals. Therefore, Sunan Kudus teaches how to be a virtuous and noble person, because if someone is ugly then the human being is getting away from God. The application of polite, polite and ethical behavior in the young generation can be used to fortify themselves from the negative effects of modernization and globalization which, if not fortified, will ravage people's lives in all fields.

2. Ji or ngaji, as hard skills here is an abbreviation of the recitation which means learning. Learning taught by Sunan Kudus. Reciting, especially studying the Islamic book to find out how the relationship with God in order to get closer to God. This is still in the Kudus community to this day with evidence that most of the younger generation who are in 
Kudus studying both through formal and non-formal institutions, even students from outside the holy flock to study in this city. In addition, studying here is not just learning Islamic books, but also learning about life and socializing with fellow human beings. With the Koran that is applied to the Holy community, it will become an intelligent person.

3. Gang of dagang, trade is a unique character that is intended to be built by Sayyid Ja'far Sadiq. The trading business that Sayyid Ja'far Sadiq is trying to make is an honest trade. Thus, gusjigang's behavior is generally characterized by elements of entrepreneurship. Generally they have the foresight of reading opportunities, are creative, and are always subject to fear so that they can survive in social opposition.

\subsection{Mind Mapping Model Based On Gusjigang Local Wisdom}

The Gusjigang-based Mind Mapping model is a learning model in which there are integrated student character values in Gusjigang (good, the Koran, and trade) with the aim of broadening insight and developing student creativity, so students can understand the material quickly and do assignments a lot of tasks easily. The form of learning implementation design using the Mind Mapping model based on the Kudus Local Wisdom is as follows:

1. Conveying the competencies to be achieved

2. Question and answer by students with good and polite language (the value of good gusjigang is "Gus")

3. Read the material before the teacher presents the concept (the value of the "Ji" Ngaji gusjigang)

4. Conveying concepts using images, video or original media

5. Forming discussion groups of 3-4 students (adjusting the number of students in one class);

6. Discuss according to submissions distributed by the teacher by noting alternative answers to the discussion.

7. Forming new groups with different submathering groups; one of the values of Gusjigang ("Gang" of trade) is to find a work partner;

8. Divide the paper and colored pencils to start making Mind Mapping from the collection of submersion.

9. Presentation in turn; included in Gusjigang's value because he had to be nice, read the results of his group, and be confident

10. Conclude the results of the discussion and presentation

\section{RESEARCH METHOD}

\subsection{Type of Research}

This type of research uses research and development methods or Research and Development (R\&D). Research and development or Research and Development (R\&D) is a research method used to produce certain products and test the effectiveness of these products (Sugiyono, 2015: 407). In this study, researchers developed the Mind Mapping learning model into a model that produces interesting learning so that students are more interested in the learning process.

In this study, researchers used a development model according to Sugiyono, the development model of Borg and Gall (2015: 409). Research and development (R\&D) method can be simplified in the following steps: (1) potential and problems; (2) data collection; (3) product design; (4) design validation; (5) design revisions; (6) product trials; (7) product revisions; (8) trial use. Simplification of the steps in research and development is due to limited time, energy, and costs in research. 


\subsection{Data Collection Techniques}

1. Observation Method, Observation as a data collection technique of teacher and student observation in learning mind Mapping models in class,

2. Interview Method, Structured and unstructured interviews conducted on teachers and students before the research and after the study.

3. Test Method, the purpose of using the test is to determine student achievement after studying the material through the Mind Mapping model based on the Holy Local Wisdom of Gusjigang in class IV.

4. Documentation Method, which is done at the time of documentation is to document photographs in learning according to the syntax, and documentation of the work results of student worksheets and test results.

5. Questionnaire, used to find out the analysis of the needs of teachers and students on the development of mind mapping models based on local wisdom Gusjigang.

\subsection{Data analysis of the Model Test phase}

To test the effectiveness of the development of this model, use Classroom Action Research (CAR). Testing the effectiveness of learning through CAR can be done by measuring the increase in learning outcomes from pre-cycle, cycle I, and cycle II. If the learning outcomes in the second cycle are better or have increased from the first cycle, then the learning model developed is also declared effective.

\section{Research Results and Discussion}

\subsection{Attitude Aspects}

From the results of the effectiveness test, the average attitude aspects in the three elementary schools of research have reached the criteria of Very Good. Of the three elementary schools, the average student who reaches the criteria of Very Good at the end of the cycle is more than $80 \%$. The details are SD 1 Gribig in cycle I obtains an average of $86 \%$ and $91 \%$ in the second cycle, SDIT Lukman Hakim in the first cycle gets an average percentage of $84 \%$ and in the cycle gets an average percentage of $91 \%$. Whereas SD 1 Gamong in cycle I gained a percentage of $83 \%$ and in cycle II gained $89 \%$.

In line with Gusviani (2016), according to him, Indonesian human figures graduating from basic education should have the following characteristics: 1) Growing faith and piety towards God Almighty; 2) Growing ethical attitudes (polite and civilized); 3) Grow good reasoning (want to learn, want to know, enjoy reading, have innovation, take initiative and be responsible); 4) Grow communication / social skills (orderly, aware of the rules, can work together with friends, can compete); 5) Growing awareness to maintain a healthy body.

4.2 Aspects of Knowledge

\begin{tabular}{|l|l|c|c|c|c|c|c|}
\hline \multirow{2}{*}{ No } & \multirow{2}{*}{ The name of School } & \multicolumn{4}{|c|}{ Efectivity test } \\
\cline { 3 - 7 } & & \multicolumn{2}{|c|}{ Cycle before } & \multicolumn{2}{c|}{ cycle I } & \multicolumn{2}{c|}{ cycle II } \\
\cline { 3 - 7 } & & PPKn & B. I & PPKn & B. I & PPKn & B. I \\
\hline 1 & SD I Gribig & $61 \%$ & $53 \%$ & $84 \%$ & $79 \%$ & $100 \%$ & $92 \%$ \\
\hline 2 & SDIT Lukman Hakim & $65 \%$ & $61 \%$ & $83 \%$ & $78 \%$ & $100 \%$ & $91 \%$ \\
\hline 3 & SD 1 Gamong & $47 \%$ & $41 \%$ & $82 \%$ & $76 \%$ & $100 \%$ & $88 \%$ \\
\hline
\end{tabular}


From the results of the effectiveness test, the average classical completeness of pre-cycle, cycle I and cycle II has increased very well. At the end of the second cycle the classical completeness of students in three elementary schools was already quite high, namely above $85 \%$ with KKM 75. SD 1 Gribig with the number of students 38 got the results of classical completeness in PPKn in cycle I by $84 \%$ and increased in cycle II with a percentage of $100 \%$ which means all students have completed. While the content of Indonesian language lessons in the first cycle got a $79 \%$ percentage and increased in the second cycle to $92 \%$ with three children who have not yet completed the KKM. Furthermore, from SDIT Lukman Al Hakim with the number of students 23 students get the results of classical completeness in the content of PPKn lessons in cycle I with a percentage of $83 \%$ and an increase in cycle II of $100 \%$ which means all students are complete. While the content of Indonesian language lessons in cycle I received a percentage of $78 \%$ and increased to $91 \%$ with two students who had not yet completed the KKM. Furthermore, the classical completeness results from Gamong Elementary School with a total of 17 students, has a percentage of PPKn load in the first cycle of $82 \%$ and has increased to $100 \%$ which means all students are complete. While the content of the Indonesian language in the first cycle obtained a percentage of $76 \%$ and increased in the second cycle to $88 \%$ with two students not completing the KKM.

Based on the information above, it can be concluded that the classical completeness using the Mind Mapping model based on the Local Wisdom of Kudus Gusjigang in class IV on theme 1 semester 1 The Beautifulness of Togetherness has increased in each cycle with the final acquisition in the second cycle is very high with a percentage in each school reaching more than $85 \%$. This is the same as stated by Kurniawati (2014) according to her mind Mapping class is superior to creativity and mastery learning with the results of classical learning completeness class.

\subsection{Skills Aspects}

\begin{tabular}{|r|l|c|c|c|c|c|c|}
\hline \multirow{2}{*}{ No } & \multirow{3}{*}{ The Name Of School } & \multicolumn{6}{|c|}{ Skills Aspects average } \\
\cline { 3 - 7 } & & \multicolumn{2}{|c|}{ Cycle before } & \multicolumn{2}{|c|}{ Cycle I } & \multicolumn{2}{c|}{ Cycle II } \\
\cline { 3 - 7 } & & PPKn & BI & PPKn & BI & PPKn & BI \\
\hline 1 & SD 1 Gribig & 74 & 73 & 82 & 81 & 85 & 84 \\
\hline 2 & SDIT Lukman Hakim & 77 & 74 & 84 & 82 & 86 & 87 \\
\hline 3 & SD 1 Gamong & 72 & 73 & 82 & 81 & 83 & 82 \\
\hline
\end{tabular}

From the results of the effectiveness test, the average student skills from pre-cycle, cycle I, and cycle II have increased. SDIT Lukman Hakim led with the highest average, namely PPKn lessons in cycle I gained 84 grades and increased in cycle II with a value of 86 , while Indonesian language lessons in cycle I scored 82 and in cycle II scored 87. Furthermore SD 1 Gribig on cycle I PPKn lesson load got 82 and increased in cycle II to 85, while the load of Indonesian language lessons in cycle I got a score of 81 and increased in cycle II 84. Finally SD 1 Gamong on the load of PPKn cycle I got an average score of 82 and increased in cycle II to 83 , while the content of Indonesian language lessons in cycle I got a score of 81 and increased in cycle II to 82 . Thus the researcher can conclude that the achievement of the skill scores is already High because all the average skill scores are above 80 . As written by Hartati (2017) with the title development of image-assisted mind mapping models to improve narrative essay writing skills of fifth grade students in Semarang, saying that by controlling the intelligence and early knowledge variables, the learning model with the image-assisted Mind Mapping model is more effective than lecture learning and discussion models in improving the narrative writing skills of fifth grade elementary school students.

\section{Conclusions and Suggestions}




\subsection{Conclusions}

1. The development of the Mind Mapping learning model based on Gusjigang's local wisdom produced several components including: 1) the syntax of the model namely; 2) Social system; 3) The principle of reaction; 4) Support system; 5) Instructional impact and accompaniment impact. The model is also equipped with a Gusjigang-based local wisdom learning mind mapping learning guide model. The book components are as follows: 1) cover, 2) introduction, 3) theoretical foundation (Gusjigang Mind Mapping learning model and local wisdom), 4) concept of mind mapping model based on Gusjigang local wisdom, 5) instructions for implementing mind mapping based on local wisdom Gusjigang, and 6) learning devices.

2. The resulting model is declared effective in elementary schools, especially in class IV. This is evidenced by an increase in learning outcomes in three elementary schools on aspects of attitude, knowledge, and skills.

\subsection{Suggestions}

1. For teachers as managers of learning it is recommended that the application of mind-based learning models based on local wisdom of Gusjigang is still conveyed to students for inculcation of character values that are Gusjigang concept.

2. For schools it is hoped that there will be efforts in the preservation of local wisdom in Kudus such as Gusjigang for its students, instilling a sense of pride and love for the environment and the region.

3. Students are expected to love, preserve, and understand the local wisdom that is around. 


\section{References}

Arikunto, Suharsimi. 2010. Prosedur Penelitian Suatu Pendekatan Praktik. Jakarta: PT Rineka Cipta

Buzan, Tony. 2012. Buku Pintar Mind Map. Jakarta: PT Gramedia Pustaka Utama

Gusviani, Evi. 2016. Analisis Kemunculan Sikap Spiritual Dan Sikap Sosial Dalam Kegiatan Pembelajaran IPA Kelas IV SD Yang Menggunakan KTSP Dan Kurikulum 2013. Universitas Pendidikan Indonesia p-ISSN 2085-1243 Vol. 8. No.1 Januari 2016 | Hal 96-10096

Hartati, dkk. 2017. Pengembangan Model Mind Mapping berbantuan gambar untuk meingkatkan keterampilan menulis karangan narasi siswa kelas V di kota Semarang. Seminar nasional PGSD tahun 2017, UNNES (diakses tanggal 18 januari 2019, pukul 21.56)

Huda, Miftahul. 2013. Model-Model Pengajaran dan Pembelajaran. Yogyakarta: Pustaka Pelajar Offset

Ismaya, Erik Aditia. 2013. Artikel Falsafah Gusjigang sebagai Modal Sosial Membangun Masyarakat Kudus yang Sejahtera disampaikan di seminar nasional Ikatan Sosiologi Indonesia dan Himpunan Indonesia untuk Pengembangan Ilmu-ilmu Sosial.

Ismaya, Erik Aditia. 2013. Model of Moral Education Based on Local Culture Gusjigang Involving Three Components. Proceedings APNME 26-30 Juni 2013, Yogyakarta: UNY

Kurniawati, Saptorini, 2014. Penerapan Mind Mapping Dan Catatan Tulis Susun Terhadap Kreativitas Dan Ketuntasan Belajar. Jurnal UNNES : ISSN NO 2252-6978

Sugiyono. 2010. Metode Penelitian Pendidikan. Bandung: Alfabeta

Suprijono, Agus. 2012. Cooperative Learning Teori dan Aplikasi PAIKEM. Yogyakarta: Pustaka Pelajar

Swadarma, Doni. 2013. Penerapan Mind Mapping dalam Kurikulum Pembelajaran. Gramedia. Jakarta. 